\title{
How Everyone Including Physicians Can Influence Overall Patient Experience
}

\author{
Raymond Malloy* and Jerin Juby \\ Thomas Jefferson University, United States
}

Submission: March 05, 2019; Published: March 21, 2019

*Corresponding author: Raymond Malloy, Senior Administrator, Thomas Jefferson University, 111 S. 11th Street, Philadelphia, PA 19107, United States

\section{Background}

Patient satisfaction and the overall experience of our patients is at the forefront of what leadership has tasked each discipline to develop ways to contribute to our overall scores. There are 3 things that patients score us on that translate to their overall experience: nurses treat with courtesy and respect, physicians explain in language that we understand, and staff works together. Based on this, we committed to provide education for hospital staff including physicians and measure our success based on our overall likelihood to recommend.

Keywords: Patient satisfaction; Nurses; Discipline; Courtesy; Respect; Hypothesize

\section{Hypothesis}

We hypothesize that most clinicians and physicians do not know their scores, have never read the questions that patients are asked related to respect, being courteous, physician communication and cannot verbalize action plans to increase the overall likelihood to recommend.

\section{Method}

We made the decision to create a quick learning tool that managers, directors, and chairs could utilize during staff meetings, leadership rounding on patients, clinicians, and physicians, during huddles, division meetings to engage their departments on the importance of increasing our overall patient experience. The tool consisted of why patient satisfaction was important, how we all play a role in our scores, current scores, quick tips to increase scores, financial impact, how we hold ourselves and each other accountable, and reviewing the questions that patients are asked during the survey.

\section{Primary outcome}

During the training sessions, we asked for feedback on the training. The following questions were asked: Was it valuable; have you read the questions related to physician communication; are the tips to improve communication helpful; did you know what drives the overall patient satisfaction score; have you ever received your scores; do you know how much your institution receives/loses annually based on your patient satisfaction scores?

The feedback was consistent that most physicians have never considered the financial impact of patient satisfaction nor what questions are asked related to communication.

\section{Secondary outcome}

The clinicians and physicians felt that the training was helpful though requested more frequent updates and monthly tips for success. They also requested to continue with monthly updates on their scores and continuing this momentum to that the training doesn't fall off the radar. Accountability is something that was discussed and holding each other to live our service standards to assure every patient encounter and employee engagement is striving for a $10 / 10$.

\section{Results}

Table 1.

Table 1: Training schedule for all the manager, physician departmental meetings.

\begin{tabular}{|c|c|c|}
\hline Discipline & Total Sessions & Month \\
\hline Physicians/Providers & Several & Ongoing \\
\hline Registered Nurses & 8 & Oct 2018 - April 2019 \\
\hline Other Clinicians & 6 & $\begin{array}{c}\text { Oct 2018 - March } \\
2019\end{array}$ \\
\hline $\begin{array}{c}\text { Environmental and } \\
\text { Dietary Services }\end{array}$ & 2 & March -19 \\
\hline
\end{tabular}

\section{Discussion}

A variety of education and rounding are completed weekly and monthly in hospitals and physician practices, all relating to the patient experience. Continuous Survey Readiness for the Joint Commission preparedness, At Your Service (AYS) Rounding to enhance employee engagement and patient satisfaction, and Environment of Care (EoC) rounding for cleanliness and facilities related deficiencies. From our experience, the following are identified to be key drivers to patient satisfaction: 
a) Environment: Clean clutter-free environment

b) Communication: Effective communication, in a way patient can understand, speaking respectfully, and effective listening

c) Staff Engagement and Teamwork: Staff (including physicians) engaging each other positively

d) Sustaining Excellence: Sustaining the efforts and maintaining patient experience as a high-priority item.

\section{Conclusion}

If patients feel safer and that we are delivering our care with higher quality, the overall perception of the hospital will increase, translating into increased overall scores. A breakdown in communication could cause the patient to call back after discharge from a hospital or an outpatient visit, return to the emergency room, or could seek another facility. This leads to unnecessary emergency room visits, and increased readmission rates due to a lack of adherence to discharge instructions, thereby increasing costs.

Physician communication is a key factor in the overall patient experience. The following four questions make-up the overall physician communication domain: Doctors treat with courtesy/ respect; Doctors listen carefully to you; and Doctors explain in way you understand. Awareness of these among physicians and training to improve the communication skills will improve the patient experience.

\section{Future}

We believe that improved patient experience is directly related to length of stay, readmissions, and overall healthcare costs. Improving the overall experience may directly impact these, and ultimately the well-being of the patient. Further research is appropriate to explore this.

Your next submission with Juniper Publishers will reach you the below assets

- Quality Editorial service

- Swift Peer Review

- Reprints availability

- E-prints Service

- Manuscript Podcast for convenient understanding

- Global attainment for your research

- Manuscript accessibility in different formats

( Pdf, E-pub, Full Text, Audio)

- Unceasing customer service

Track the below URL for one-step submission https://juniperpublishers.com/online-submission.php 